\title{
Russelliánský monismus jako svébytné metafyzické stanovisko
}

\author{
Jakub Mihálik \\ Filosofický ústav \\ Akademie věd České Republiky \\ Jilská 1, 11000 Praha 1 \\ mihalik@flu.cas.cz
}

Příspěvek kriticky reaguje na pojednání o russelliánském monismu v monografii Jaké to je, nebo o čem to je? Tomáše Hř́bka. Podle Hříbka russelliánský monismus, př́stup k fenomenálnímu vědomí inspirovaný vhledy Bertranda Russella, nepředstavuje skutečnou alternativu vi̊či materialismu, dualismu a idealismu. Autor př́spěvku argumentuje, že russelliánský monismus naopak lze pokládat za svébytné metafyzické stanovisko, jež se navíc vyhýbá hlavním úskalím těchto tradičních přístupů. Nejprve odpovídá na námitku, že fundamentální jsoucna neutrálního monismu jsou ve skutečnosti mentalistická, a tedy nikoli neutrální. V souvislosti s neutrálním monismem rovněž poukazuje na problémy Hř́ibkovy definice fyzikalismu v duchu via negativa. Autor dále vysvětluje, proč na rozdíl od dualismu nepředstavuje pro russelliánský monismus vážnou obtíž kauzální uzávěra fyzična, a upozorňuje, že russelliánský monismus dokáže lépe než materialismus odpovědět na výzvy, jako jsou argument z myslitelnosti a argument z poznání. Ačkoli tedy russelliánský monismus má s materialismem, dualismem a idealismem jistě styčné plochy, daří se mu vyhnout nejvážnějším obtížím těchto směrů, a máme proto dobrý důvod chápat jej jako svébytný a slibný př́ístup k fenomenálnímu vědomí.

Existuje přesvědčivá alternativa $\mathrm{k}$ materialistickému, dualistickému a idealistickému přístupu k fenomenálnímu vědomí? ${ }^{1}$ Vzhledem k tomu, že obě zmíněná tradiční pojetí vztahu vědomí a fyzického světa čelí vážným námitkám, tato otázka se jeví jako klíčová. Není proto náhoda, že se v posledních letech ocitla v centru zájmu řady filosofů. U nás se jí opakovaně věnoval Tomáš Hříbek: nejprve časopisecky pojednal o hylemor-

1 Dále budu k fenomenálnímu vědomí referovat jednoduše termínem „vědomí“. 
fickém př́stupu² a nyní se ve své monografii zabývá russelliánským monismem, přistupem k problému mysli a těla, inspirovaným myšlenkami Bertranda Russella. ${ }^{3}$ Právě na Hříbkovo užitečné a erudované pojednání o tomto přístupu bych se rád zaměřil ve svém př́íspěvku.

Na úvodní otázku Hř́bek odpovídá záporně: dospívá k závěru, že russelliánský monismus není stabilní pozice, nebot jeho hlavní varianty kolabují do forem materialismu, ${ }^{4}$ dualismu či idealismu, a tak se nejedná o skutečnou alternativu vůči nim. ${ }^{5}$ Ačkoli se domnívám, že Hříbek správně poukazuje na to, že některé varianty russelliánského monismu se bliží dualismu a jiné fyzikalismu a ještě jiné idealismu, existují, jak ukáži, dobré důvody, proč lze russelliánský monismus i přesto pokládat za slibnou alternativu $\mathrm{k}$ těmto tradičním pojetím. Jak se totiž pokusím ukázat, russelliánský monismus se úspěšně vyhýbá jejich hlavním úskalím.

\section{Co je russelliánský monismus?}

Russelliánský monismus je přístup k vědomí, který volně vychází z Russellova pojetí vztahu mezi vjemy (percepts) a fyzickým světem, představeného mj. v knize The Analysis of Matter ${ }^{6}{ }^{6}$ Russellův přistup, jehož paralely nalezneme např. u Ernsta Macha, Williama Jamese, Herberta Feigla či Arthura Eddingtona, vychází z myšlenky, že nám fyzika neříká o povaze mikrofyzických složek reality nic, co by vylučovalo možnost, že alespoň některé $\mathrm{z}$ nich mají niternou povahu vjemů.7 $\mathrm{Z}$ fyziky totiž podle Russella sice čerpáme nepřeberné množství přesných, matematizovatelných poznatků o mikrofyzickém světě, avšak tyto poznatky se týkají pouze strukturních či relačních vlastností mikrofyzických událostí, a jsou proto vysoce abstraktní. Fyzika nám tedy neodhaluje, jakou niternou povahu (intrinsic nature) tyto události mají, jsou-li uvažovány samy

2 Hř́bek (2012).

3 Tamtéž, 3. kap.

4 Stejně jako Hříbek zde chápu „fyzikalismus“ a „materialismus“ jako synonyma.

5 Hř́ibek (2017, s. 108).

6 Viz např. Russell (1927), Russell (1959/1995). O Russellově přístupu jsem podrobněji pojednal v článku Mihálik (2013).

7 Russell (1927, s. 384). 
o sobě. Pokud Russellovy poznámky o mikrofyzických událostech vztáhneme na mikrofyzická jsoucna, můžeme např́klad - s trochou zjednodušení - říci, že o elektronu se z fyziky dozvídáme, že jde o jsoucno, které přitahuje protony, odpuzuje jiné elektrony a chová se neutrálně vůči neutronům (přičemž tato ostatní jsoucna a vztahy jsou opět charakterizovány pouze relačně). Nedozvídáme se však nic o tom, čím je elektron sám, uvažovaný mimo složitou sít fyzikálních vztahů specifikovaných prírodními zákony.

Jediné fyzické události, které poznáváme i jinak než pouze po strukturní stránce, jsou podle Russella naše vlastní vjemy. ${ }^{8} \mathrm{U}$ nich jsme obeznámeni i s jejich niternou, kvalitativní povahou, u vjemu modré oblohy tak např́klad poznáváme specifický odstín modra. To vede Russella k hypotéze, že i další fyzické události, mají vnitřní povahu vjemů, přičemž tato jejich povaha nutně stojí mimo dosah fyzikálního zkoumání. ${ }^{9}$ Russellova hypotéza představuje podnětný pokus integrovat vědomé stavy s jejich kvalitativní povahou do světa popisovaného fyzikou. Pokud si totiž uvědomíme meze svého fyzikálního poznání, nahlédneme podle Russella, že tato kvalitativní povaha může mít své pevné místo př́imo ve fundamentálním předivu universa, a kvalitativní povaha vjemů, jež zakoušíme $\mathrm{v}$ rámci svého vlastního vědomého života, tak - vzhledem k tomu, že jsme fyzické bytosti - nebude překvapivá.

Své pojetí Russell označuje jako neutrální monismus, přičemž výraz „neutrální" má poukazovat na to, že fundamentální složky universa nemají ani mentální, ani fyzickou povahu. Jak fyzická, tak mentální sféra jsou tedy nefundamentální a - můžeme říci - derivované z neutrálního materiálu. Neutrální monismus se tak prima facie odlišuje jak od materialismu, podle něhož je fyzikální sféra fundamentální a mentální sféra odvozená, tak od dualismu, podle něhož je jak fyzikální, tak mentální sféra fundamentální. Výraz „monismus“ má poukazovat na to, že - v protikladu $\mathrm{k}$ dualismu - existuje jen jeden typ fundamentálních složek universa. Neutrální monismus tedy je, pokud použijeme rozlišení zavedené Alterem a Nagasawou, variantou typového monismu (type monism), a nikoli instančního monismu (token monism). ${ }^{10}$ Zatímco podle

8 Tamtéž, s. 389.

9 Tamtéž.

10 Alter \& Nagasawa (2015b, s. 423). 
typového monismu existuje na fundamentální úrovni pouze jediný typ jsoucen, podle instančního monismu existuje na fundamentální úrovni dokonce pouze jediné jsoucno. ${ }^{11}$

Russellovu stanovisku se v době jeho publikace, stejně tak jako po celý zbytek 20. století, dostalo málo filosofické pozornosti. Většího zájmu se tento originální přístup dočkal až v posledních dvou dekádách, přičemž různé Russellem inspirované přístupy dnes bývají souhrnně označovány jako russelliánský monismus. ${ }^{12}$ Tento termín tak v současné debatě označuje obecnější přístup k vědomí, který nelze ztotožnit s pojetím Russella samotného. Torin Alter a Yujin Nagasawa definují russelliánský monismus jako konjunkci tř́i tezí: ${ }^{13}$

\section{1. strukturalismus ohledně fyziky \\ 2. realismus ohledně nevyzpytatelností \\ 3. (proto)fenomenální fundamentalismus}

Tyto teze se nyní pokusím objasnit. Obsah první z nich byl již naznačen: zastánci russelliánského monismu se domnívají, že základní vlastnosti popisované fyzikou jsou strukturní či relační. Tyto vlastnosti se, jak jsme viděli u Russella, týkají relačně definovaných rolí, jež fyzikální jsoucna sehrávají v dané teorii (tedy toho, co dané jsoucno v rámci fyzického světa dělá). Strukturalismus ohledně fyziky zastávaný russelliánskými monisty je však epistemologický, a nikoli ontologický, týká se tedy mezí fyzikálního poznání, a nepředstavuje tezi o fundamentální povaze skutečnosti. Russelliánští monisté tedy - na rozdíl od ontologických strukturalistů jako Ladyman, Ross a dalšsí14 - nezastávají, že realita má v posledku čistě strukturní povahu. Jsou totiž zastánci realismu ohledně nevyzpytatelností, přičemž nevyzpytatelnosti (inscrutables) jsou podle

11 Variantu instančního monismu slavně obhajoval Spinoza, v současných debatách nalezneme jeho varianty např. u Horgana a Potrče (2000) a Schaffera (2010). Pod nálepku instančního monismu spadají i varianty kosmopsychismu, viz např. Goff (2017), Shani (2015), Nagasawa \& Wager (2017) a Albahari (v tisku).

12 Viz např. Chalmers (1996), Rosenberg (2004), Strawson (2006), Alter \& Nagasawa (2015a), Brüntrup \& Jaskolla (2017).

13 Alter \& Nagasawa (2015, s. 425).

14 Ladyman, Ross et al. (2007). 
nich fundamentální vlastnosti, které nejsou strukturní a které realizují mikrofyzické role definované fyzikou. ${ }^{15}$ Tyto vlastnosti bývají označovány jako niterné (intrinsic), nebot' se týkají toho, jaké mikrofyzické jsoucno samo o soběje (a tedy nikoli toho, co dělá). ${ }^{16}$ Zároveň, jak jejich název napovídá, není jejich povaha odhalitelná metodami fyziky.

Koncepce, v jejímž rámci teoretické role vyžadují realizanty, se mi, podobně jako Russellovi, jeví jako přesvědčivější než koncepce ontologických strukturalistů, podle nichž veškerou realitu lze redukovat na čistou strukturu. Russell o takovémto čistě strukturním světě napsal, že $\mathrm{v}$ něm - obrazně řečeno - jsou všechny věci jen omýváním něčeho jiného (all the things in the world will merely be each other's washing). ${ }^{17}$ Jinými slovy, zdá se, že pokud strukturu vysvětlujeme pomocí vztahů, pak předpoklad, že existuje struktura, znamená, že musí existovat jsoucna, která tyto vztahy realizují a sama nemají čistě relační povahu. Právě těmito jsoucny jsou zmíněné nevyzpytatelnosti.

Russelliánští monisté navíc předkládají pozitivní návrh ohledně povahy nevyzpytatelností, konkrétně tezi (proto)fenomenálního fundamentalismu. Podle této teze jsou alespoň některými nevyzpytatelnostmi fenomenální nebo protofenomenální vlastnosti. Fenomenální vlastnosti chápou russelliánští monisté tradičně, jako vlastnosti našich vědomých stavů, na základě kterých - slovy Thomase Nagela - je to pro nás nějaké (there is something it is like) nacházet se v těchto stavech. ${ }^{18}$ Př́lkladem fenomenální vlastnosti je zakoušené specifické modro oblohy za jasného dne nebo zakoušená sladká chut vanilkové zmrzliny. Protofenomenální vlastnosti jsou, zhruba řečeno, zvláštní vlastnosti, které samy nejsou fenomenální, avšak pokud utvoří kompaktní a náležitě uspořádaný systém, pak společně konstituují fenomenální vlastnosti. ${ }^{19}$ Někteří zastánci russelliánského panprotopsychismu přitom předkládají pozitivní návrhy ohledně povahy protofenomenálních vlastností, z nichž některé níže

15 Termín „nevyzpytatelnost“ používá Barbara Montero a další. Viz např. Montero (2015).

16 Pokud mluvím o nevyzpytatelnostech v množném čísle, ponechávám tím stranou holistické varianty russelliánského monismu, podle kterých existuje jen jediná nevyzpytatelnost. Tato stanoviska spadají pod nálepku instančního monismu (viz vysvětlení výše a literatura v pozn. 11).

17 Russell (1927, s. 325).

18 Nagel (1974).

19 Bohužel zde není prostor pro přesnější definici protofenomenálních vlastností. Zajímavý pokus o ni předložil Goff (2015). 
představím. Podle jiných je pro nás povaha těchto vlastností alespoň prozatím kognitivně uzavřena. ${ }^{20}$

Existují tedy dvě hlavní varianty russelliánského monismu: podle russelliánského panpsychismu jsou alespoň některými nevyzpytatelnostmi fenomenální vlastnosti. Podle russelliánského panprotopsychismu jsou alespoň některými nevyzpytatelnostmi protofenomenální vlastnosti. Pokud nám zmíněná teze (proto)fenomenálního fundamentalismu ř́ká, že alespoň některými nevyzpytatelnostmi jsou fenomenální nebo protofenomenální vlastnosti, je zároveň na místě tázat se, zda russelliánský monismus skutečně platí za variantu typového monismu. Domnívám se, že př́sně vzato jde o typový monismus pouze tehdy, pokud všechny nevyzpytatelnosti jsou fenomenální, nebo tehdy, pokud jsou všechny protofenomenální. Pokud naopak platí, že pouze některé nevyzpytatelnosti jsou fenomenální, nebo že pouze některé nevyzpytatelnosti jsou protofenomenální, budou ve výsledném obrázku vždy přinejmenším dva druhy nevyzpytatelností. Některé varianty russelliánského monismu slučitelné se třemi kritérii Altera a Nagasawy jsou tak variantami typového monismu jen podle jména, nebot jsou slučitelné s existencí několika rozdílných typů nevyzpytatelností. ${ }^{21}$

Má ale vůbec smysl o russelliánském monismu v kontextu současných debat uvažovat? Myslím, že ano, nebot' mnozí filosofové souhlasí s Davidem Chalmersem, že existence fenomenálního vědomí představuje z hlediska standardních metod kognitivní vědy těžký problém ${ }^{22} \mathrm{a}$ russelliánský monismus nabízí plodné pole pro úvahy o řešení tohoto problému. Jak by však předpoklad fenomenálních či protofenomenálních nevyzpytatelností mohl s těžkým problémem pomoci?

Uvažme nejprve fenomenální nevyzpytatelnosti. Pokud mikrofyzická jsoucna vykazují primitivní fenomenální vlastnosti, je prima facie nepřekvapivé, že organismus, který je mikrofyzickými jsoucny tvořen, rovněž vykazuje fenomenální vlastnosti, jakkoli v mnohem komplexnější podobě. Zdá se přirozené tvrdit, že celek zde zdědí vlastnosti svých

\footnotetext{
20 Viz Stoljar (2001, s. 274).

21 I Russellovo stanovisko bylo snad typovým monismem jen podle jména. Viz např. Russell (1995, s. 18).
}

22 Chalmers (1995). 
částí, analogicky k tomu, jak tomu je u hmotnosti či elektrického náboje. Russelliánští panpsychisté se pokusili nabídnout různá vysvětlení způsobu, kterým z mikro-vědomí fundamentálních fyzických jsoucen vzniká makro-vědomí celého organismu, přičemž někteří z nich jsou zastánci konstitutivního russelliánského panpsychismu, podle něhož množství mikro-fenomenálních vlastností konstituuje za podmínky určitého typu komplexního uspořádání makro-fenomenální vlastnosti. ${ }^{23}$

Obratme nyní pozornost k protofenomenálním nevyzpytatelnostem. Pokud mikrofyzická jsoucna vykazují protofenomenální vlastnosti, je málo překvapivé, že organismus, který je mikrofyzickými jsoucny tvořen, vykazuje fenomenální vlastnosti. Protofenomenální vlastnosti jsem konec konců výše charakterizoval jako zvláštní vlastnosti, které samy o sobě nejsou fenomenální, avšak pokud společně utvoří náležitě uspořádaný systém, konstituují fenomenální vlastnosti.

Ne všichni jsou ohledně potenciálu russelliánského monismu vyřešit těžký problém vědomí optimističtí. Mnozí upozorňují na fakt, že není vůbec jasné, jak by složitě organizovaný systém primitivních mikrofenomenálních vlastností mohl utvořit vědomé stavy organismů, jako jsme my. ${ }^{24}$ Jiní zase proti russelliánskému monismu namítají, že zastánci tohoto př́stupu nedokáží dostatečně uspokojivě vyjasnit vztah strukturních vlastností a nevyzpytatelností. Tomáš Hříbek některé z těchto obtíží zmiňuje, nicméně jeho hlavní kritika russelliánského monismu mírí jinam: russelliánský monismus podle něj nepředstavuje skutečnou alternativu vůči fyzikalismu, dualismu či idealismu. Podívejme se, jaké úvahy jej k tomuto skeptickému závěru přivádějí.

\section{Mohou existovat neutrální jsoucna?}

Klasickou variantu russelliánského panprotopsychismu představuje neutrální monismus, jemuž se Hř́bek kriticky věnuje nejdříve. ${ }^{25}$ Definuje

23 Obhajobě konstitutivního russelliánského panpsychismu se podrobně věnuji v knize Mihálik (2016).

24 Touto obtíží, tzv. problémem kombinace, se detailně zabývá např. Chalmers (2017).

25 Je na místě zde připomenout, že russelliánský monismus nelze ztotožnit s Russellovým neutrálním monismem. Jak již bylo řečeno, „russelliánský monismus“ v literatuře souhrnně označuje šíře chápaný, Russellem volně inspirovaný přístup k vědomí. 
jej jako přístup, podle něhož fundamentální vlastnosti nejsou ani fyzické, ani mentální. ${ }^{26}$ To nás vede k otázce, jak Hř́ibek chápe fyzické a mentální vlastnosti. Jeho odpověd’ vychází z pojetí Herberta Feigla, ${ }^{27}$ který je zastáncem tzv. aposteriorního přístupu $\mathrm{k}$ definici fyzikální vlastnosti. ${ }^{28}$ Na rozdíl od klasických materialistů, kteří se pokoušeli dospět k definici hmoty pomocí apriorní analýzy pojmu hmoty, se Feigl odvolává na nejlepší fyzikální teorie. Vlastnost je podle něj fyzikální právě tehdy, pokud je vyjádřena predikátem takovéto teorie.

Feiglův návrh však naráží na výzvu formulovanou Carlem Hempelem, jenž upozornil, že z takovéto charakterizace vůbec není jasné, o jaké fyzikální teorii je řeč. ${ }^{29}$ Máme za fyzikální považovat ty vlastnosti, o nichž mluví naše nejlepší teorie, nebo jde o vlastnosti, o nichž bude mluvit budoucí ukončená fyzika, k níž snad jednou dospějeme?30 Tyto otázky nás staví před tzv. Hempelovo dilema. Pokud fyzikální vlastnosti vymezuje nejlepší současná fyzikální teorie, je materialismus, chápaný jako teze, že všechny vlastnosti jsou fyzikální, téměř jistě nepravdivý, nebot’ budoucí fyzika téměř jistě odhalí vlastnosti, o nichž ta současná neví. Pokud naopak fyzikální vlastnosti má vymezit teprve budoucí ukončená fyzika, zdá se, že toho o fyzických vlastnostech víme tak málo, že nejsme schopni vyhodnotit otázku, zda je fyzikalismus pravdivý. Od ukončené fyziky, pokud je vůbec dosažitelná, nás totiž podle všeho dělí velmi dlouhá doba, během níž může dojít k vědeckým revolucím.

Hempelovo dilema nicméně podle Hř́bka nepředstavuje pro definici fyzických vlastností nepřekonatelný problém. Způsob, kterým náš autor na toto dilema odpovídá, bývá v literatuře označován jako via negativa. ${ }^{31}$ Zastánci via negativa přijímají možnost, že budoucí fyzika může objevit nové vlastnosti, které se mohou podstatně lišit od vlastností postulovaných dnešní fyzikou, a upozorňují, že nemáme důvod vylučovat je ze sféry fyzična. Dodávají však, že materialismus platí pouze tehdy, pokud nově objevené vlastnosti budou nementální. $V$ opačném případě nás fy-

26 Hř́ibek (2017, s. 112).

27 Tamtéž, s. 49-53.

28 Hříbek, nakolik je mi známo, nerozlišuje mezi „fyzickou vlastností“ a „fyzikální vlastností“. Proto předpokládám, že tyto termíny použivá synonymně.

29 Hempel (1980, s. 194-195).

30 Viz Hill (2014) pro skepsi ohledně návrhu, že lidský druh je schopen dospět k ukončené fyzice.

31 Viz např. Montero \& Papineau (2005). 
zika jednoduše dovede $\mathrm{k}$ nějaké formě panpsychismu. Hř́bek tak - v duchu této vlivné strategie - definuje fyzické vlastnosti jednoduše jako nementální vlastnosti. ${ }^{32}$ Takováto definice samozřejmě vyžaduje, abychom věděli, co jsou mentální vlastnosti. Podle Hř́bka jsou to bud' vlastnosti intencionální, tedy takové, díky nimž naše mentální stavy (např. přesvědčení či přání) reprezentují stavy světa, nebo vlastnosti fenomenální.

Ve světle tohoto pojetí fyzických vlastností se nám Hříbkovo chápání neutrálních vlastností, které nemají být ani fyzické, ani mentální, může jevit jako potenciálně vnitřně rozporné. Pokud jsou totiž neutrální vlastnosti nefyzické, znamená to s ohledem na Hř́bkovu definici fyzikalismu, že jsou mentální. Právě to však popírá druhá část Hříbkovy definice neutrálních vlastností, podle níž tyto vlastnosti nemají být mentální. Jak se můžeme tomuto rozporu vyhnout?

Jedna možnost zní doplnit Hříbkovu definici fyzikálních vlastností a definovat je jako ty vlastnosti, které nejsou ani mentální ani neutrální. Taková modifikace by však byla možná pouze tehdy, pokud bychom už rozuměli tomu, co to znamená, že je nějaká vlastnost neutrální. Jak jsme ale viděli, Hř́ibkova definice neutrální vlastnosti se právě spoléhá na pojem fyzické vlastnosti. Tato možnost se proto jeví jako málo slibná.

Slibnější by snad bylo, kdyby se Hř́bek odchýlil od via negativa a poskytl nám substantivnější definici fyzikálních vlastností. Jeden takový návrh představil Chalmers, který píše - snad ovlivněn Russellem -, že se fyzika zabývá „strukturou a dynamikou světa např́ic prostorem a časem“. ${ }^{33} \mathrm{~V}$ souladu s tímto návrhem by pak fyzické vlastnosti představovaly rysy struktury universa a jejích proměn $\mathrm{v}$ čase. Takové pojetí by nabízelo prostor pro neutrální vlastnosti, které nejsou ani fyzické (tzn. netýkají se čistě struktury a dynamiky), ani mentální (tzn. nejsou ani intencionální, ani fenomenální). Pokud bychom se naopak drželi Hříbkovy definice, zdá se, že možnost skutečně neutrálních jsoucen je a priori vyloučena. Hříbkův závěr, že neutrální monismus je určitou formou idealismu, nebo fyzikalismu, je pak nicméně pouze logickým důsledkem jeho definice fyzických vlastností, což jej činí nepříliš zajímavým.

32 Hř́bek (2017, s. 53).

33 Chalmers (1996, s. 36). Viz také Prelević (2017, s. 504) pro návrh, jak Chalmersovo pojetí fyzična může posloužit při charakterizaci fyzikalismu jako výzkumného programu. 
Předpokládejme proto, že máme $\mathrm{k}$ dispozici definici fyzických vlastností, která není čistě negativní, a můžeme tedy pracovat i s výše představenou definicí neutrálních vlastností. Uvažme nyní Hříbkův návrh, že neutrální monismus ve skutečnosti kolabuje do nějaké formy idealismu, případně fyzikalismu. ${ }^{34}$ Nejprve si položme otázku, zda neutrální monismus ve skutečnosti není variantou idealismu.

Za klíčovou v této souvislosti považuje Hř́bek námitku, že údajně neutrální jsoucna, postulovaná neutrálními monisty, mají ve skutečnosti mentální či ideální charakter. Přesvědčivosti této námitky nasvědčuje fakt, že zastánci neutrálního monismu údajná neutrální jsoucna často nazývají termíny, které mají mentální konotace. Russell, jak jsme viděli, mluví o vjemech, Mach zase o počitcích (Empfindungen). ${ }^{35}$ Pokud by se tato námitka ukázala být oprávněnou, stavělo by to neutrální monismus podle Hř́bka do velmi neatraktivního světla, nebot idealismus je podle něj př́liš bizarní stanovisko na to, aby jej v rámci současných debat bylo možné brát vážně. ${ }^{36}$

Pro zhodnocení této námitky uvažujme nad tím, co Hříbek míní idealismem. Idealistický přístup Hř́bek charakterizuje jako pojetí, podle něhož fenomenální popis světa je vyčerpávajícím popisem světa. ${ }^{37}$ Takováto charakterizace nám vlastně ř́ká, že veškerá realita je plně založena ve fenomenálních stavech subjektů.$^{38}$ Pokud idealismus chápeme takto, zdá se mi jeho návrh, že neutrální monismus kolabuje ve formu idealismu, obtížně obhajitelný. Russellův přistup, který jsem stručně načrtl na úvod tohoto příspěvku, nám totiž neposkytuje důvod domnívat se, že jsou kauzální vztahy, prostor a čas založeny ve fenomenálních stavech subjektů. Navíc je v něm kladen zřetelný důraz na existenci světa vnějšího vůči vnímatelům. I kdybychom navíc připustili, že mohou existovat formy idealismu, u nichž fenomenální stavy nemusejí plně zakládat prostor, čas a kauzální vztahy a u nichž existuje vnější svět, není vůbec zřejmé, že - navzdory jménu - jsou podle Russella vjemy vědomé, a tedy

34 Hř́ibek (2017, s. 115).

35 Mach (2008).

36 Hř́ibek (2017, s. 18).

37 Tamtéž, s. 18.

38 Je otázka, jestli někdo zastává takto silnou verzi idealismu. Nelze ji podle všeho přisoudit Berkeleymu, nebot’ bychom kromě jeho teologie pominuli i jeho substanciální pojetí mysli. 
fenomenální, pokud zrovna nefigurují v náležitých kauzálních vztazích $\mathrm{v}$ rámci fungujícího mozku. ${ }^{39}$

Snad nejslibnější a nejpropracovanější současnou formou neutrálního monismu je pankvalitismus (panqualityism), obhajovaný Samem Colemanem. Podle Colemana je universum na fundamentální úrovni tvořeno nezakoušenými, tedy nevědomými kvalitami. ${ }^{40}$ Kvality jsou podle Colemana zakoušeny pouze tehdy, pokud se stanou předmětem myšlenky vyššího řádu, což je podle všeho možné pouze ve fungujícím mozku. Kvality samy o sobě tak v Colemanově pojetí je třeba odlišovat od fenomenálních vlastností. Pankvalitismus navíc netvrdí, že jsou prostor, čas a kauzální vztahy plně založeny ve fenomenálních stavech subjektů. Navíc i tento přístup klade důraz na existenci vnějšího světa, jenž není redukovatelný na vjemy vědomých pozorovatelů. Tyto úvahy o formách neutrálního monismu, které nalezneme u Russella a Colemana, mě vedou k závěru, že neutrální monismus nelze považovat za variantu idealismu.

\section{Je russelliánský panpsychismus variantou dualismu?}

Přejděme nyní ke Hř́ibkově námitce, podle které russelliánský panpsychismus, který představuje další rozšířenou variantu russelliánského monismu, je ve skutečnosti formou dualismu. Takový návrh se může zdát zjevně pomýlený, pokud máme na mysli tradiční dualismus substancí, od něhož se russelliánský panpsychismus zdá velmi odlišný. Jak je tomu však s návrhem, že je russelliánský panpsychismus ve skutečnosti variantou atribučního dualismu, tedy stanoviska, podle něhož v universu existují vedle fyzických vlastností též nefyzické fenomenální vlastnosti?

Právě k tomuto návrhu se Hř́ibek přiklání. S odkazy na pasáže z Chalmerse a Nagela upozorňuje, že russelliánský panpsychismus zmíněnou charakterizaci atribučního dualismu splňuje, nebot’ nám říká, že existuje radikální rozdíl mezi fyzikálními a fenomenálními vlastnostmi. ${ }^{41} \mathrm{Na}$ rozdíl od tradičních forem atribučního dualismu sice tvrdí, že fenomenální vlastnosti nejsou vykazovány pouze některými komplexními organismy,

39 Russell (1927, s. 385).

40 Viz např. Coleman (2017).

41 Hříbek (2017, s. 124). 
nýbrž také fundamentálními jsoucny, nicméně může se zdát, že i přesto jde o dualistické stanovisko.

Domnívám se, že i kdybychom připustili atribučně dualistickou interpretaci russelliánského panpsychismu, je třeba si uvědomit, že se tento přístup zároveň dualismu podstatně vymyká a má oproti němu podstatné přednosti. Abychom je nahlédli, připomeňme, že klíčová obtíž dualismu spočívá v tom, že implikuje kauzální vyloučení fenomenálních vlastností z fyzického světa. Pokud jsou totiž podle atribučního dualismu fenomenální vlastnosti nefyzické, je jejich kauzální působnost v rozporu s tzv. principem kauzální uzávěry fyzična. ${ }^{42}$ Tento princip nám říká, že každý fyzický do̊sledek má fyzickou příčinu. Vzhledem k tomu, že kauzální uzávěra fyzična zjevně vylučuje nefyzické příčiny fyzických dějů, stojí dualista před následujícím trilematem:

(1) může přijmout princip kauzální uzávěry fyzična, čímž popře, že fenomenální vlastnosti mají kauzální působnost ve fyzickém světě, a přijme epifenomenalismus. Ten je však v příkrém rozporu s našimi intuicemi. Zdá se bizarní tvrdit, že by např́iklad zkušenost bolesti či sladké chuti čokolády nikdy neměla žádné fyzické důsledky. Dualista se sice může pokusit různými způsoby tyto obtížně přijatelné důsledky své pozice zmírnit, je ale otázka, nakolik jsou tyto pokusy přesvědčivé. ${ }^{43}$

(2) Může popřít kauzální uzávěru fyzična a přijmout interakcionismus, podle něhož mezi fyzickými vlastnostmi a nefyzickými mentálními vlastnostmi probíhají kauzální interakce. To znamená, že některé fyzické důsledky nemají fyzické, nýbrž mentální př́ičiny. Problémy interakcionismu jsou zjevné: jak kdysi Descarta slavně upozornila princezna Alžběta Falcká, není vůbec jasné, jak by mohly kauzálně interagovat dvě radikálně odlišné sféry. Interakcionista navíc sází proti principu kauzální uzávěry fyzična, v jehož prospěch mluví mnohé empirické poznatky.

(3) Dualista může dále zastávat systematickou kauzální předeterminovanost některých důsledků. To znamená, že důsledek tohoto typu má

42 Tamtéž, s. 101.

43 Viz tamtéž (s. 105) pro pojednání o epifenomenalismu u Franka Jacksona. Viz také Chalmers (1996, s. 150-160). 
vždy dvě různé, současně působící přičiny, ačkoli by pro jeho výskyt dostačovala kterákoli z těchto dvou př́čin samostatně. Tento princip se však - kromě toho, že působí silně ad hoc - zdá být v rozporu s ekonomií přírody. Není totiž vủbec jasné, proč je pro nás vědomí evolučně prospěšné, pokud se, jak nám ř́íká zastánce předeterminovanosti, veškeré naše chování mohlo odehrát totožně při absenci vědomí. ${ }^{44}$

Všechny tři představené pozice s sebou tedy nesou vysokou teoretickou nákladnost. Právě jejich obtížná přijatelnost je pro Hřribka, pokud mu správně rozumím, hlavním důvodem pro odmítnutí dualismu a př́íklon k materialismu. ${ }^{45}$ Pokud, jak se nyní pokusím ukázat, russelliánský panpsychismus tyto nepřijatelné důsledky nemá, měli bychom dobrý důvod neřadit jej mezi dualistické přístupy, nebo jej alespoň chápat jako vysoce neortodoxní dualismus.

Rozhodnutí řadit russelliánský panpsychismus $\mathrm{k}$ atribučnímu dualismu může už na první pohled působit zvláštně. Zatímco u dualismu vlastností se může zdát, že nefyzické vlastnosti jsou jaksi navíc přidány k fyzickým vlastnostem, u russelliánského panpsychismu tomu tak není. Jak jsme viděli, fenomenální vlastnosti tu jsou totiž nevyzpytatelnostmi, které představují niternou povahu fundamentálních mikrofyzických jsoucen. Pokud tedy nějaké mikrofyzické jsoucno kauzálně působí na jiné, zdá se přirozené říci, že kauzální práci tu vykonává právě příslušná nevyzpytatelnost, tedy fenomenální vlastnost.

Jak jsme viděli, pro dualismus představuje vážnou hrozbu teze kauzální uzávěry fyzična, která dualistu staví před trilema interakcionismu, epifenomenalismu a systematické kauzální předeterminovanosti. Jaký je vztah této teze k russelliánskému panpsychismu? Abychom mohli odpovědět na tuto otázku, bude užitečné zavést zde Chalmersovo rozlišení mezi široce a úzce fyzikálními vlastnostmi. Široce fyzikální vlastnosti tento myslitel chápe jako mikrofyzikální role, jako např́klad role hmotnosti či náboje, společně s nevyzpytatelnostmi, jež tyto role realizují.

44 Jak mě upozornil James Hill, Hříbkův výčet by dále mohl obsahovat psycho-fyzický paralelismus, podle něhož mohou probíhat kauzální interakce ve fyzické sféře, v mentální sféře, avšak nikoli mezi těmito dvěma sférami.

45 Hř́ibek (2017, s. 105). 
Patří sem tedy jak vlastnosti dispoziční, tak kategorické základy těchto dispozic. Úzce fyzikální vlastnosti jsou pak pouze mikrofyzikální role či dispozice uvažované bez svých realizantů, kategorických základů. Mezi úzce fyzikální vlastnosti elektronu tak např́iklad patří jeho různé dispozice k chování, avšak nikoli jeho niterná povaha. Mezi vlastnosti široce fyzikální pak patří jak jeho dispozice, tak jeho niterná povaha, která může být, jak jsme viděli, (proto)fenomenální. ${ }^{46}$

Nyní můžeme rozlišit mezi dvěma variantami kauzální uzávěry. Kauzální uzávěra širokého fyzična platí, pokud všechny důsledky mají široce fyzické příčiny, tedy příčiny zahrnující výskyt široce fyzických vlastností. Kauzální uzávěra úzkého fyzična platí, pokud všechny důsledky mají úzce fyzické příčiny, tedy příčiny zahrnující výskyt úzce fyzických vlastností. Jak upozornil Chalmers, russelliánský panpsychismus je plně slučitelný s kauzální uzávěrou širokého fyzična, nebot’ jeho zastánci mají dobrý důvod zastávat, že všechny do̊sledky mají příčiny zahrnující nevyzpytatelnosti a jimi realizované mikrofyzikální role. ${ }^{47}$ Russelliánský panpsychismus naopak není slučitelný s kauzální uzávěrou úzkého fyzična. Jeho zastánci však - a to je podstatné - mají dobrý důvod tuto variantu uzávěry odmítnout, nebot’ podle nich právě nevyzpytatelnosti konají ve fyzickém světě nezastupitelnou kauzální práci - realizují totiž fyzikou vymezené mikrofyzikální role.

Zde je možné namítnout, že se russelliánským panpsychistům sice snad podařilo zajistit kauzální působnost pro mikrofenomenální vlastnosti, nikoli však pro makrovědomí našeho typu. Je ale namístě pochybovat o tom, že se tato námitka vztahuje na konstitutivní russelliánský panpsychismus, který nám říká, že makrovědomí je konstituováno velkým množstvím mikrofenomenálních vlastností, které jsou nevyzpytatelnostmi. Pokud totiž vztah konstituce chápeme jako vztah, který naprŕiklad platí mezi molekulami a stolkem, který společně tvoří, zdá se přirozené tvrdit, že stolek zdědí kauzální působnost po svých konstituentech. I kdyby však - a to je podstatné - konstitutivním russelliánským panpsychistům hrozilo kauzální vyloučení makrovědomí, budou analo-

46 Chalmers (2015, s. 182-183).

47 Tamtéž, s. 187. 
gické obtíži čelit též fyzikalisté, pokud nebudou chtít zastávat, že veškerá kauzalita je fundamentální kauzalita.

Pokud, jak jsem argumentoval, se na russelliánský panpsychismus nevztahuje obtíž s kauzální uzávěrou fyzična, klíčová pro Hříbkovu kritiku dualismu, máme dobrý důvod chápat russelliánský panpsychismus jako pozici, která není v žádném tradičním smyslu dualistická. ${ }^{48}$ Pro to mluví i fakt, že fenomenální realizanty lze v russelliánském monismu přirozeně chápat jako fundamentálnější než realizované fyzikální role. To ovšem posouvá russelliánský panpsychismus směrem k neortodoxní verzi idealismu (slabší než je ta představená Hříbkem), jakkoli je, na druhé straně, russelliánský panpsychismus - na rozdíl od standardního idealismu - zjevně slučitelný s tezemi, že čas a prostor nejsou založeny ve fenomenálních faktech a že platí robustní realismus ohledně vnějšího světa. ${ }^{49}$ Russelliánský panpsychismus tak lze chápat jako návrh podoby idealismu, která se vyhýbá „neuvěřitelnému“ pojetí vědomí, o němž mluví Hř́bek, ${ }^{50}$ a která zároveň není v rozporu s široce chápaným naturalismem. Primitivní fenomenalita je totiž v rámci tohoto přistupu integrálním aspektem fundamentálního přediva fyzického světa.

\section{Russelliánský monismus a fyzikalismus}

Pokud jsem v předchozím oddíle napsal, že fenomenální nevyzpytatelnosti patří mezi široce fyzické vlastnosti, může se zdát, že jsem tím uznal, že russelliánský panpsychismus je ve skutečnosti formou fyzikalismu, a tak nemůže představovat skutečnou alternativu k němu. Ve skutečnosti by však drtivá většina fyzikalistů russelliánský panpsychismus jistě odmítla. Russelliánský panpsychismus je samozrejmě nefyzikalistický také podle Hř́bkovy definice fyzikalismu, nebot' postuluje neredukovatelné fenomenální vlastnosti. To znamená, že pro většinu fyzikalistů je široký fyzikalismus až příliš široký. Je nicméně zajímavá otázka, zda,

48 Hříbek se mnou, zdá se mi, souhlasí, že russelliánský panpsychismus má - na rozdíl od atribučního dualismu - potenciál vyhnout se epifenomenalismu, ale omezuje se na stručnou poznámku (Hříbek 2017, s. 103). Já jsem se pokusil uvážit tento bod v širším kontextu Hříbkovy argumentace.

49 Více viz Chalmers (v tisku).

50 Hř́bek (2017, s. 18). 
jak navrhuje Hříbek, existují varianty russelliánského monismu, které je možné přiřadit $\mathrm{k}$ fyzikalismu standardnímu.

Je zřejmé, že nejlepšími kandidáty na fyzikalistickou formu russelliánského monismu budou některé verze russelliánského panprotopsychismu. Russelliánští panprotopsychisté totiž, jak jsme viděli, nepostulují fundamentální fenomenalitu, nýbrž pouze fundamentální protofenomenální vlastnosti, jejichž existence není v očividném rozporu s fyzikalismem. Hř́bek v této souvislosti upozorňuje na zajímavý př́stup Barbary Monterové, která argumentuje, že pokud protofenomenální vlastnosti (1) nejsou - uvažovány jednotlivě - „poskvrněny“ fenomenalitou (ačkoli v rámci komplexních systémů společně fenomenalitu konstituují) a zároveň (2) zakládají nejen fenomenální vědomí samotné, nýbrž také celek universa, nestojí nic v cestě tomu, abychom je chápali jako v tradičním smyslu fyzické. ${ }^{11}$

Může tedy existovat russelliánský fyzikalismus? Souhlasím s Hříbkem a Monterovou, že v principu nic nestojí v cestě tomu, abychom některé varianty russelliánského panprotopsychismu označovali jako fyzikalistické, nicméně si nejsem jist, zda by většina fyzikalistů byla ochotna takovýto russelliánský fyzikalismus připustit jakožto variantu své nauky, vzhledem k tomu, že jeho zastánci spoléhají při vysvětlení vědomí na zvláštní protofenomenální vlastnosti, které jsou, jak lze argumentovat, navíc - jakožto nevyzpytatelnosti - nepřístupné metodám fyziky. Většina fyzikalistů (resp. fyzikalisté typu A a B v rámci Chalmersovy klasifikace, na niž Hř́ibek odkazuje) má, domnívám se, naopak za to, že naše fyzika už je dostatečně vyspělá na to, abychom dokázali vědomí vysvětlit (alespoň pokud jsme patřičně revidovali své chápání tohoto fenoménu), nebo alespoň dokázali pochopit, proč pro bytosti s naší pojmovou výbavou není vědomí transparentně vysvětlitelné..$^{2} \mathrm{~V}$ tomto smyslu se vyjadřuje např́klad Daniel Dennett, když se podivuje nad tím, že se jeho „reakčni" antifyzikalističtí oponenti obracejí s nadějí na vysvětlení vědomí $\mathrm{k}$ fyzice a jejímu možnému dalšímu vývoji. ${ }^{33}$

Z hlediska russelliánských panprotopsychistů nicméně standardní fy-

51 Montero (2015, s. 217).

52 První alternativa je typická pro fyzikalisty typu A, druhá pro fyzikalisty typu B.

53 Dennett (2005, s. 8). 
zikalistické přístupy samozřejmě nenabízejí uspokojivé vysvětlení vědomí a russelliánský panprotopsychismus proti nim má podstatnou výhodu v tom, že postuluje fundamentální protofenomenální vlastnosti. Díky tomu se tomuto směru daří přesvědčivě odpovědět na hlavní antifyzikalistické argumenty. Zdá se totiž, že scénář se zombiemi nebude myslitelný, pokud tyto naše fyzické a funkční repliky zahrnují na fundamentální úrovni protofenomenální vlastnosti. ${ }^{54}$ Podobně Marie z Jacksonova myšlenkového experimentu ${ }^{55}$ bude, lze argumentovat, schopná vydedukovat, jaké to je vidět červenou, na základě své znalosti protofenomenálních vlastností (a př́slušných strukturních vlastností). I typem své odpovědi na tyto argumenty se tak russelliánský panprotopsychismus, včetně jeho fyzikalistické varianty, liší od standardního fyzikalismu.

Domnívám se tedy, že je možné některé varianty russelliánského panprotopsychismu označit za fyzikalistické, kladu si nicméně otázku, nakolik russelliánský fyzikalismus může být v diskusi o vědomí užitečný, pokud pojetí protofenomenálních vlastností, s nímž pracuje, je téměř úplně obsahově vyprázdněné - víme vlastně jen, že má jít o zvláštní fyzikální vlastnosti, které za určitých podmínek společně konstituují makrofenomenalitu a zároveň realizují mikrofyzikální role. Není tak jistě náhoda, že realizanty nevyzpytatelností postulované přístupy, jako jsou pankvalitismus nebo Russellův neutrální monismus, se z hlediska fyzikalistického pohledu na svět mohou jevit jako př́liš exotické, tj. mentalistické. Pokud jsou totiž protofenomenální vlastnosti nevyzpytatelnostmi nepř́stupnými fyzikálnímu zkoumání, můžeme o nich jasnější představu nabýt právě jen z perspektivy první osoby. To z nich nicméně - alespoň nakolik platí výše představená argumentace - nečiní mentální vlastnosti.

Souhlasím tedy s Hř́bkem, že některé varianty russelliánského monismu se blíží fyzikalismu, nicméně vzhledem $k$ tomu, že postulují zvláštní protofenomenální vlastnosti jakožto nevyzpytatelnosti, jsou zároveň, domnívám se, od standardních forem fyzikalismu dostatečně odlišné. Jde tak o fyzikalismus, který je zřetelně russelliánský.

54 Podrobněji viz Chalmers (2015).

55 Viz např. Jackson (2003). 


\section{Závěr}

Pokusil jsem se oponovat Hříbkovu závěru, že russelliánský monismus není svébytná ontologická pozice, nýbrž se rozpadá na varianty dualismu, fyzikalismu a idealismu. Argumentoval jsem, že ačkoli russelliánský monismus jistě má se zmíněnými směry styčné plochy, daří se mu vyhnout nejvážnějším obtížím těchto směrů. Dospívám tedy k závěru, že je - navzdory Hříbkovu podnětnému a užitečnému pojednání - russelliánský monismus dostatečně svébytný na to, aby byl potenciálně slibnou alternativou tradičních nauk. Jistou míru různorodosti v rámci tohoto přístupu, zdá se mi, dobře kompenzují výše popsané společné rysy jeho různých variant i fakt, že russelliánský monismus otevírá zajímavé cesty v oblasti, ve které tradiční př́istupy selhávají..$^{56}$

\section{Literatura}

Albahari, M. (v tisku): „Beyond Cosmopsychism and the Great I Am: How the World Might Be Grounded in Universal ,Advaitic Consciousness." In The Routledge Handbook of Panpsychism, ed. W. Seager, Oxford University Press, New York.

Alter, T. \& Nagasawa, Y., eds. (2015a): Consciousness in the Physical

World. Perspectives on Russellian Monism. Oxford University Press, New York.

Alter, T. \& Nagasawa, Y. (2015b): „What is Russellian Monism?“ In Alter \& Nagasawa (2015a): 422-451.

Brüntrup, G. \& Jaskolla, L., eds. (2017): Panpsychism. Contemporary Perspectives. Oxford University Press, New York.

Coleman, S. (2017): „Panpsychism and Neutral Monism: How to Make up One’s Mind.“ In Brüntrup \& Jaskolla (2017): 249-282.

Dennett, D. (2005): Sweet Dreams. Philosophical Obstacles to a Science of Consciousness. MIT Press, Cambridge.

56 Za podnětné připomínky k předchozím verzím textu děkuji Jamesi Hillovi a anonymnímu recenzentovi. 
Goff, P. (2015): „Against Constitutive Russellian Monism.“ In Alter \& Nagasawa (2015a): 370-400.

Goff, P. (2017): Consciousness and Fundamental Reality. Oxford University Press, New York.

Hill, J. (2014): „Noam Chomsky's Critique of Materialism: An Appraisal." Teorie vědy 36 (4): 437-455.

Hill, J. \& Mihálik, J., eds. (2015): Vědomí bez redukce. Antologie esejů ze současné filosofie mysli. SMRŠŤ, Praha.

Horgan, T. \& Potrč, M. (2000): „Blobjectivism and Indirect Correspondence." Facta Philosophica 2: 249-270.

Hř́bek, T. (2012): „Materialismus a hylemorfismus.“ Filosofický časopis 60 (4): 585-600.

Hř́bek, T. (2017): Jaké to je, nebo o čem to je? Místo vědomív materiálním světě. Filosofia, Praha.

Chalmers, D. (1995): „The Puzzle of Conscious Experience.“ Scientific American 237 (6): 62-68.

Chalmers, D. (1996): The Conscious Mind. In Search of the Fundamental Theory. Oxford University Press, New York.

Chalmers, D. (2015): „Panpsychismus a panprotopsychismus.“ In Hill \& Mihálik (2015): 168-213.

Chalmers, D. (2017): „The Combination Problem for Panpsychism.“ In Brüntrup \& Jaskolla (2017): 179-214.

Chalmers, D. (v tisku): „Idealism and the Mind-Body Problem.“ In The Routledge Handbook of Panpsychism, ed. W. Seager, Oxford University Press, New York.

Jackson (2003): „The Knowledge Argument.“ Richmond Journal of Philosophy 3: 1-6.

Ladyman, J., Ross, D. et al. (2007): Everything Must Go: Metaphysics Naturalized. Oxford University Press, Oxford. 
Mach, E. (2008): Die Analyse der Empfindungen. Xenomoi Verlag, Berlin.

Mihálik, J. (2013): „Russellův neutrální monismus a problém vědomí.“

In Studie k filosofii Betranda Russella, eds. M. Soutor, T. Marvan \& L. Dostálová, Filosofia, Praha, 2013, s. 189-204.

Mihálik, J. (2016): Vědomí v př́rodě. Russellovský přístup. SMRŠŤ, Praha.

Montero, B. (2015): „Russellian Physicalism.“ In Alter \& Nagasawa (2015a): 209-223.

Montero, B. \& Papineau, D. (2005): „A defence of the via negativa argument for physicalism." Analysis 65 (3): 233-237.

Nagel, T. (1974): „Jaké je to být netopýrem?“ In Hill \& Mihálik (2015): 19-38.

Nagasawa, Y. \& Wager, K. (2017): „Panpsychism and Priority Cosmopsychism." In Brüntrup \& Jaskolla (2017): 113-129.

Prelević, D. (2017): „Hempel's Dilemma and Research Programmes: Why Adding Stances Is Not a Boon.“ Organon F 24 (4): 487-510.

Rosenberg, G. (2004): A Place for Consciousness. Oxford University Press, New York.

Russell, B. (1927): The Analysis of Matter. Kegan Paul, London.

Russell, B. (1995): My Philosophical Development. Routledge, London.

Shani, I. (2015): „Cosmopsychism: A Holistic Approach to the Metaphysics of Experience." Philosophical Papers 44 (3): 389-437.

Schaffer, J. (2010): „Monism: The Priority of the Whole.“ Philosophical Review 119 (1): 31-76.

Stoljar, D. (2001): „Two Conceptions of the Physical.“ Philosophy and Phenomenological Research 62 (2): 253-281.

Strawson, G. (2006): „Realistic Monism: Why Physicalism Entails Panpsychism.“ Journal of Consciousness Studies 13 (10-11): 3-31. 


\section{Abstract \\ Russellian Monism as a Self-Standing Metaphysical Position}

The paper critically discusses the treatment of Russellian monism in Tomáš Hříbek's monograph Jaké to je, nebo o čem to je? (What It's Like, or What It's About?). According to Hř́bek, Russellian monism, the approach to phenomenal consciousness inspired by the insights of Bertrand Russell, is not a real alternative to materialism, dualism and idealism. I argue that Russellian monism, on the contrary, can be viewed as a self-standing philosophical position which, moreover, avoids the main problems of these traditional approaches. I first address the objection that the fundamental entities of neutral monism have a mental, rather than neutral nature. In connection with neutral monism, I also express some worries concerning Hř́bek's via negativa definition of physicalism. Thereafter I explain why the causal closure of the physical which poses a serious difficulty for dualism is not a problem for Russellian monism and emphasize that Russellian monism is able to tackle challenges, such as the conceivability argument and the knowledge argument, better than materialism. While then Russellian monism has certain affinities with materialism, dualism and idealism, it avoids the most serious challenges for these approaches and we therefore have a good reason to view it as a self-standing and promising approach to phenomenal consciousness.

Mihálik, J. (2017): „Russelliánský monismus jako svébytné metafyzické stanovisko." Filosofie dnes 9 (2): 23-43. Dostupné z www.filosofiednes.ff.uhk.cz. 